\title{
Behavior of Retail Investors of Jammu and Kashmir towards Various Investment Alternatives
}

\section{Ajaz Ahmad Bhat*}

Department of Commerce, Barkatullah University, Bhopal, India

\begin{abstract}
This paper is going to highlight the preferences of investors towards the various investment alternatives, as what investors going to invest their money out of the best choices of alternatives available in the market and investors also must be fully aware about the rates of the alternatives in the market. Investing in various types of alternatives is an interesting act to induce people from all walks of life with respect to their economic background and their income level, and the investors who are having extra money to invest in the other form of investment instruments. At present a wide investment alternatives are open to invest the investor's suitable form of investment alternatives like real estate and bank deposits etc.to conduct the present study the primary survey has been done and the data is been collected via questionnaire for the fulfilment of the present study.
\end{abstract}

Keywords: Investor; Investment; Alternatives rates; Money

\section{Introduction}

No gain without pain this is what we called investment. In today's scenario, money plays an important role in one's life. In order to overcome the problems in future one has to invest his or her money. Investment may be defined as sacrifice of certain present value for some uncertain future value. In other words, investment means the purchase of a financial product with an expectation of future returns. It is defined investment as the funds which are invested as capital or other securities of either public or private sector for earning more money. It is the employment of funds with the aim of earning additional income. Investment as instead of keeping money idle uses that money so that you may get higher returns. There are various types of investment options available in the market such as financial, physical, marketable and nonmarketable and transferable and non-transferable. A person prefers to invest in particular investment according to his or her suitability and needs. There are some of the ideal investment programs such as safety, liquidity, regularity of income, capital appreciation and many more. Investment aims at multiplication of money at higher or lower rates depending upon whether it is a long term or short term investment and whether it is risky or risk free investments. They explained investment as purchase of a financial product with an expectation of getting higher returns in future.

\section{Definition}

Profit is the reward on investment

\section{Objectives of investment alternatives}

Income: This is one of the main and foremost objectives of any investment to earn the income in the form of dividend and interest.

Capital appreciation: The capital appreciation is also the aim or objective of the investment which can be achieved by conservative growth, aggressive growth and speculation.

\section{Forms of return}

The return means reward on investment and it is two forms of two types, periodic cash receipts and the capital gain.

\section{Safety of funds}

Safety of funds means keeping funds in safe place. This is the best objective of any investor who can invest their money should be secure and safe.

\section{Risk}

The investor who wants to earn more profit or return should be ready to take more risk.

\section{Liquidity}

The investors should invest or prefer on those investments which are liquid in nature.

\section{Tax considerations}

Provisions of capital gain, income tax, and others so that tax burden should be minimized.

\section{Classification of Investments}

\section{Physical investments}

These are those investments which are having real existence in nature are called tangible assets such as buildings, machinery, gold and others.

\section{Financial investments}

These are investments are those investments which are used for production of goods or for creation of assets.

\section{Objectives}

- To study the investment behaviour towards investment alternatives in Jammu and Kashmir

*Corresponding author: Bhat AA, Department of Commerce, Barkatullah University, Bhopal, India, Tel: +9149436440; E-mail: bhatajazg@gmail.com

Received December 19, 2017; Accepted January 31, 2018; Published February 07, 2018

Citation: Bhat AA (2018) Behavior of Retail Investors of Jammu and Kashmir towards Various Investment Alternatives. Bus Eco J 9: 339. doi: 10.4172/21516219.1000339

Copyright: $\odot 2018$ Bhat AA. This is an open-access article distributed under the terms of the Creative Commons Attribution License, which permits unrestricted use, distribution, and reproduction in any medium, provided the original author and source are credited. 
- To Study the perceptions of different age groups towards various financial investments.

\section{Literature Review}

Rahej and Lambha [1] from this study, we can say that the money plays an important role in one's life. So in order to have safe future one should convert their savings into investment. The people with different age groups prefer different investment options for different objectives behind investment. The portfolio of the academicians must consider the behaviour of the academicians before making any investment. The study concludes that there are various investment avenues available in the market. The different people prefer to invest in different avenues according to their choice. It also concludes that life cycle stages and investment objectives are dependent on each other.

Investor behaviour often deviates from logic and reason. Emotional processes mental mistakes, and individual personality traits complicate investment decisions. Thus, investing is more than just analysing numbers and making decisions to buy and sell various assets and securities. A large part of investing involves individual behaviour. Ignoring or failing to grasp this concept can have a detrimental influence on portfolio performance.

Massa and Simonov [2] analyse portfolio holdings of Swedish investors and document that investors tilt their portfolio towards stocks that are most closely related to them, either professionally (e.g., A financial professional investing in a finance stock) or geographically (e.g., a Seattle investor investing in a Seattle stock). They argue that this familiarity-based investing allows investors to earn higher returns because of the information advantage conferred by familiarity.

Ranganathan [3] states that financial markets are affected by the financial behaviour of investors and consumer behaviour from the marketing world and financial economics had brought together a need to study an exciting area of 'behavioural finance' and thus studying the behaviour of investors holds importance.

Rajakumar [4] studies that customer' attitude towards purchase of insurance products concludes that there is a low level of awareness about insurance products among customers in India.

On impact of investors' lifestyle on their investment pattern: an empirical study states that the modern investor is a mature and adequately groomed person. Occasions of blind investments are scarce, as a majority of investors are found to be using some source and reference groups for taking decisions [5].

Weber and Welfens [6] confirm in experiments that subjects exhibit this behaviour! Only when they were responsible for the original sale, suggesting that investors refrain from repurchasing stocks at a higher price than their previous sale price to avoid regret.

Kumar [7] shows those individuals prefer stocks with high idiosyncratic volatility, high idiosyncratic skewness, or low stocks prices. He further shows that the same demographic characteristics that predict lottery participation (e.g., education, income, and religious affiliation) also predict the strength of lottery-like preferences in stocks.

This is an empirical survey of the factors, which mostly influence individual investor behaviour in the Indian stock market [8]. The results revealed that there seems to be a certain degree of correlation between the factors that behavioural finance theory and previous empirical evidence identify as the influencing factors for the average equity investor, and the individual behaviour of active investors in the Bombay Stock Exchange (BSE) influenced by the overall trends prevailing at the time of the survey in the BSE.

Concluded that women are more conservative and takes less risk and significant gender differences occur in investment preferences for health insurance, fixed deposits and market investments among employees.

Palanivelu and Chandrakumar [9] highlights that certain factors of salaried employees like education level, awareness about the current financial system, age of investors etc. make significant impact while deciding the investment avenues.

Kathuria and Singhania [10] concluded that private sector banking employees were investing a larger portion of their savings into safe and risk-free investment avenues, like employee provident fund, public provident fund and life insurance policy and only forty per cent of the respondents had high level of awareness regarding various investment avenues.

Sultana [11] concluded that individual investor still prefer to invest in financial products which give risk free returns. The study confirmed that Indian investors even if they are of high income, well-educated, salaried, and independent are conservative investors who prefer to play safe in the market.

\section{Research Methodology}

The present research or study is based on primary and secondary data set. The necessary data was collected from 200 retail investor's respondents of Jammu and Kashmir State, due to limitations of time and money researcher has applied convenience random Sampling method to gather/collect the primary data [12]. To collect the necessary information from different types of retail investors well-structured questionnaire was used as a research Instrument of data collection percentile method has been approached to analysis the data.

\section{Interpretation: gender value of respondents}

The above figure shows the respondents according to their gender state blue bar line reveals 130 are the males out of 200 hundred respondents and red bar line reveals the 70 females out of the total respondents 200 (Figure 1).

\section{Interpretation: investment preferences of alternatives}

The above figure shows the preferences of investors towards the alternatives 70 respondents are those who prefer to invest their money on shares, 10 respondents are those who prefer to invest their money

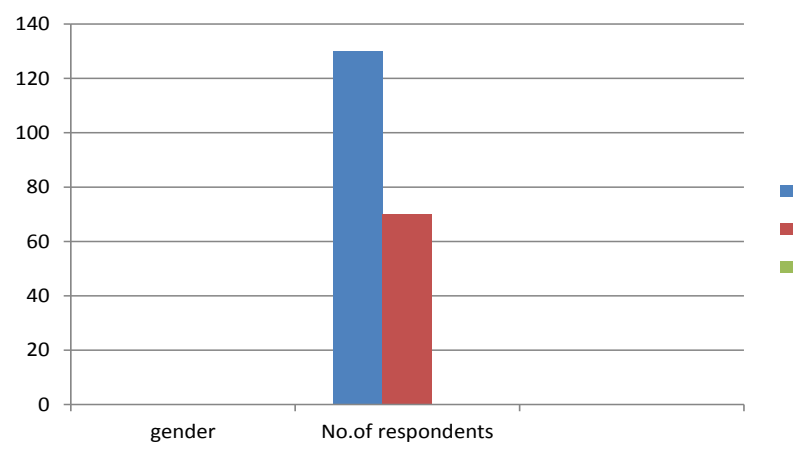

Source: Primary survey

Figure 1: Gender value of respondents. 
on debentures and bonds separately, 20 respondents are those who prefer to invest their money on mutual funds, 50 respondents are those who are willing to invest their money on real estate and 40 respondents are those who invest their money or savings on gold. Most of them who prefer to invest on shares above mentioned [13] (Figure 2).

\section{Interpretation: educational qualification}

The above figure shows the educational qualification of the respective respondents among them 15 respondents are those who are having 10th class education, 30 respondents are those who are having $10+2$ educational qualification, 60 respondents are those who are having graduation educational qualification, 90 respondents who are having PG and its highest qualification among the total respondents of the research study. And others are only 5 in numbers out of the rest respondents (Figure 3).

\section{Interpretation: rate of return}

The above research and figure indicates the 30 respondents are those who are expecting 8-10 percent of return on their investment, 50 respondents are those who are expecting 12-16 percents of return, 80 respondents are those who are expecting 16-20 percent of return on their investment, 40 respondents are those who are expecting 20 and above percents of return on their investments [14] (Figure 4).

\section{Interpretation: level of investment of knowledge}

The above figure indicates the knowledge of the investors about the investment alternatives out of the total 200 respondents the knowledge is like as 30 respondents are those who are having little knowledge

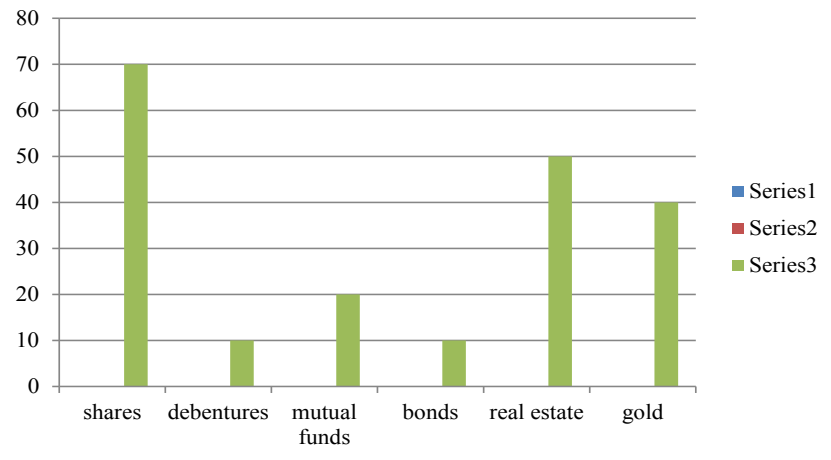

Source: Primary survey.

Figure 2: Investment preferences of alternatives.

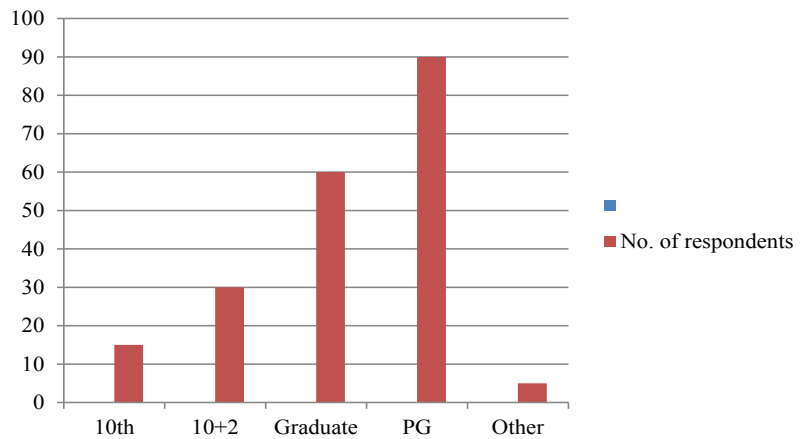

Source: Primary survey.

Figure 3: Educational qualification.

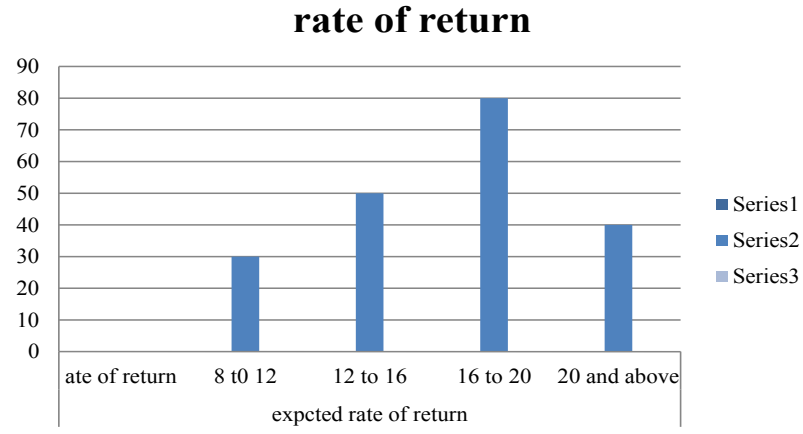

Source: Primary survey.

Figure 4: Rate of return.

\section{level of knowledge}

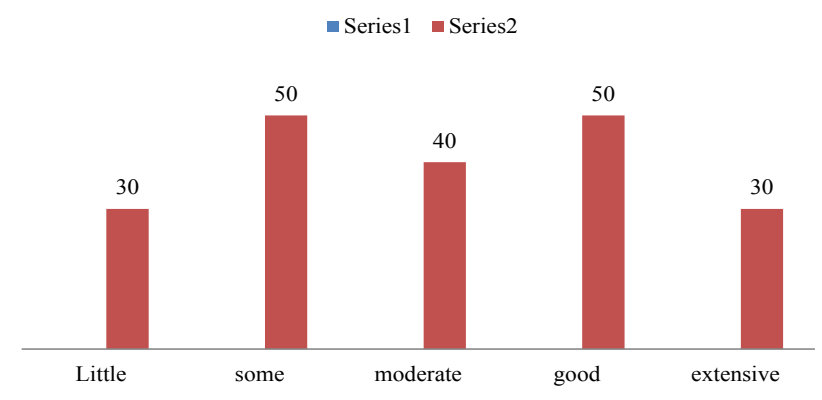

Source: Primary survey.

Figure 5: Level of investment knowledge.

about the investment, 50 respondents are both having good and some knowledge separately towards the investment alternatives, 40 and 30 respondents out of the total 200 respondents having moderate and extensive knowledge about the investment alternatives (Figure 5).

\section{Interpretation: expected rate of return}

The above bar chart shows the expected rate of return 80 respondents out of the total respondents who expects more return on their investment, 50, 40 and 30 respondents are those who expects their investment return as per their investment out of them 80 respondents and others get their return as they did invest on the respective investment alternatives (Figure 6).

\section{Interpretation: objective of investment}

Most of the retail investors have primary objective of investment is to earn regular income which accounts as 40 percents of respondents out of the total respondents. 40 percents respondent are those who particular want to achieve their investment goal, 30 respondent are those who wants safety of their capital, 15 percent respondents are those who want wealth for retirement out of the total respondents, others are 5 percent and 70 percent are those who are having multiple objectives on their investment as per their expectations on their respective investments (Figure 7).

\section{Interpretation: risk level}

The above chart shows the level of risk on the investment out of the total respondents 90 percent respondents undertake low risk, 40 and 
Citation: Bhat AA (2018) Behavior of Retail Investors of Jammu and Kashmir towards Various Investment Alternatives. Bus Eco J 9: 339. doi: 10.4172/2151-6219.1000339

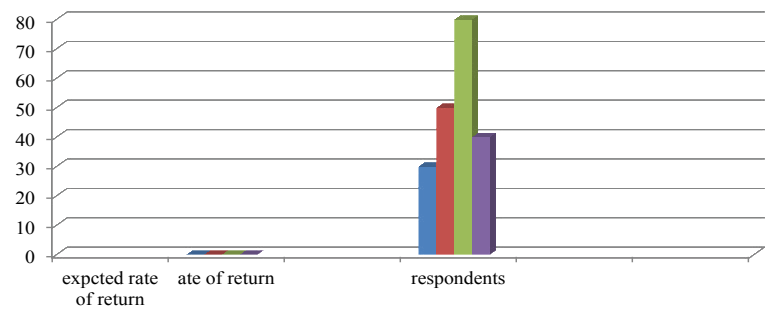

Source: Primary survey.

Figure 6: Expected rate of return.

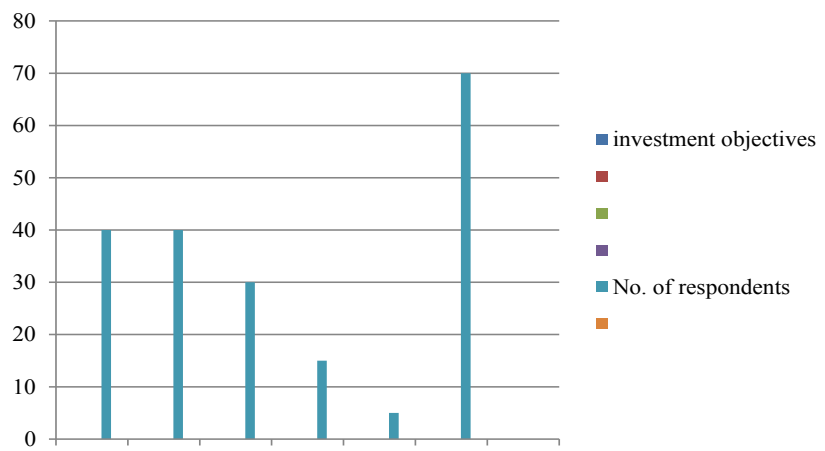

Source: Primary survey.

Figure 7: Objective of investment.

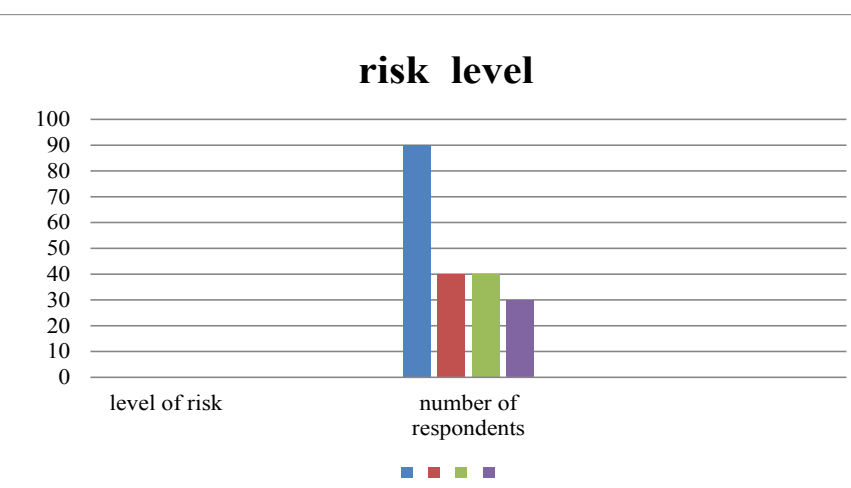

Source: Primary survey.

Figure 8: Risk level.

40 perecnt respondents are who undertakes as moderate and high level of risk on their investment, and 30 percent respondents are those who undertake only high level of risk on their investment (Figure 8).

\section{Findings}

In the study area the researcher has investigated 200 respondents and the study on sex reveals that 130 respondents are male. So it indicates or inferred that most of the investment decisions are taken by the male respondents only.

\section{Suggestions} reveals

The following suggestions are highlighted below as per the research

1. The investors has to invest their money in the less risky alternatives like, debenture, mutual funds, fixed deposits etc., because these are the alternatives which are having less or minimum risk comparing to the other alternatives.

2. As per the survey the above indicates that people of Jammu and Kashmir are investing their money on real estate. It's good to keep their money on long term investments but they must have a proper knowledge about the rates in the market.

\section{Conclusion}

The research makes a pertinent revelation that the level of investment knowledge significantly boosts or leverages the returns on the investments. From above the discussion of the frequency distribution data, it shows the variations about the respondents are having extensive knowledge regards the investment alternatives no doubt lot of the Investment alternatives are available in the market but in Jammu and Kashmir public or investors are investing their money on shares, Real Estate, fixed deposits etc., these are the alternatives which give good return on investment even having high level of risk but they assume they will give good return as more risk leads to more profit.

Hence the researcher has concluded that the most of the investors of Jammu and Kashmir investing their money in shares and followed by real estate and gold.

\section{References}

1. Raheja S, Lambha B (2013) Behaviour of Investors towards Investment. Indian Journal of Applied Research.

2. Massa M, Simonov A (2006) Hedging, Familiarity, and Portfolio Choice. Review of Financial Studies 19: 633-685.

3. Ranganathan K (2006) A Study of Fund Selection Behavior of Individual Investors towards Mutual Funds: With Reference To Mumbai City. ICFAI Journal of Behavioral Finance 3: 63-88.

4. Rajakumar DJ (2008) Studies of corporate financing and investment behavio in India: A survey. Journal of Applied Finance 14: 5-29.

5. Nagpal S, Bodla BS (2009) Impact of investors' lifestyle on their investment pattern : An empirical study. Journal of Behavioural Finance.

6. Weber M, Welfens F (2011) The Follow-on Purchase and Repurchase Behavior of Individual Investors: An Experimental Investigation. Die Betriebswirtschaft 71: 139-154.

7. Kumar A (2009) Who Gambles in the Stock Market. Journal of Finance 54:1889-1933

8. Srinivas BG, Rasure K (2010) Factors Influencing And Individual Investor Behavior: The study of Indian stock market. International Journal of Research in Commerce Economic Management.

9. Palanivelu VR, Chandrakumar K (2013) A Study on Preferred Investment Avenues among Salaried Peoples with Reference to Namakkal Taluk, Tamil Nadu, India. IBEA, International Conference on Business, Economics, and Accounting.

10. Kathuria LM, Singhania K (2012) Investment Decision Making: A GenderBased Study of Private Sector Bank Employee. The IUP Journal of Behavioral Finance 9: 45-56.

11. Sultana ST (2010) An Empirical Study of Indian Individual Investors Behavior Global Journal of Finance and Management 2: 19-33.

12. Barberis N, Xiong W (2009) What Drives the Disposition Effect? An Analysis of a Long-Standing Preference-based Explanation. Journal of Finance 64:751. 784

13. Viji S, Akilandeswari S (2016) A Study on Preferred Investment Avenues among Salaried Peoples with Reference to Namakkal Taluk, Tamil Nadu, India. International Journal of Management and Development Studies 5: 50-59.

14. Kothari H (2015) Investors behavior towards investment avenues. Altius Shodh Journal of Commerce and Management. 